\title{
Biochemical effects of ethylene diamine tetra-acetic acid (EDTA) on cadmium treated maize (Zea mays L.) and cowpea (Vigna unguiculata L.)
}

\author{
Emeke E. Agbadah ${ }^{1}$, Kenneth C. Nwachukwu ${ }^{2}$ and Michael P. Okoh ${ }^{2 \star}$ \\ ${ }^{1}$ Department of Biochemistry, Faculty of Science, Delta State University, P.M.B 1, Abraka, Delta State, Nigeria. \\ ${ }^{2}$ Department of Medical Biochemistry, College of Health Sciences, University of Abuja, P.M.B 117, FCT, Abuja, Nigeria.
}

Received 7 July, 2015; Accepted 11 March, 2016

\begin{abstract}
The effects of ethylenediaminetetra-acetic acid (EDTA) on germination, length of stem, area of leaf, fresh weight, level of lipid per oxidation, alkaline phosphatase, acid phosphatase, super oxide dismutase (SOD) and catalase in the roots of cadmium (Cd) treated maize (Zea mays $L$ ) and cowpea (Vigna unguiculata L) seedlings after 7 and 21 days of germination were determined in this study. The results obtained, indicate that at the end of 7 and 21 days of exposure to $\mathrm{Cd}$, percentage germination of the seeds were not significantly different in both control and test soil $(p>0.05)$. Morphological parameters (area of leaf, length of stem and fresh weight) were significantly reduced by $\mathrm{Cd}$ after 7 and 21 days. The supplementation of the soil sample with EDTA $(0.5 \mathrm{mM}$ or $1.0 \mathrm{mM})$ reversed the effect of $\mathrm{Cd}$ on these parameters as it significantly increased length of stems, area of leaf and plant fresh weight. There was a significant decrease in root acid phosphatase, root alkaline phosphatase, super-oxide dismutase (SOD) and catalase activity in both plant species. Both used doses of EDTA to ameliorate the above biochemical parameters. Increased level of root lipid peroxidation in Cd treated maize and cowpea seedlings was observed after 7 and 21 days of germination. Albeit, the level of lipid peroxidation in the root of $\mathrm{Cd}$ treated maize was significantly higher than that of cowpea, an indication that cowpea may be more tolerant than maize to $\mathrm{Cd}$ toxicity. The treatment of plant with, concentrations of EDTA $(0.5$ and $1.0 \mathrm{mM}$ ) failed to decrease the $\mathrm{Cd}$ induced, but increased the level of root lipid peroxidation. These results indicate that EDTA $(0.5 \mathrm{mM}$ and $1.0 \mathrm{mM})$ could be used for the treatment of Cd toxicity in plants; although, EDTA did not totally protect cowpea seedling from oxidative stress.
\end{abstract}

Key words: Heavy metal, phytoremediation.

\section{INTRODUCTION}

Cadmium is a heavy metal with, no known biological function. However, it is highly toxic to plants and animals (Chandler, 1996; Tran and Popova, 2013). Its effects on plants are manifested by inhibition of the normal uptake and utilization of mineral nutrients (Liu et al., 2003). Cadmium is thought to enter the environment mainly from industrial sources and during application of phosphate fertilizer; hence, it can be of high levels in agricultural

*Corresponding author. E-mail: okoh.michael@gmail.com, m.okoh@chsuniabuja.edu.ng. Tel: +2347035683068.

Author(s) agree that this article remains permanently open access under the terms of the Creative Commons Attribution License 4.0 International License 
soils. It is a major pollutant present in areas with heavy road traffic and near smelters and sewage sludge areas (Rascio et al., 1993). When taken up in excess, Cd can disturb almost all physiological processes in plants (Siedlecka and Baszyń-Aski, 1993). It is one of the most toxic metals in plants, active at concentration much lower than those of other heavy metals (Kudo et al., 2011). The metal can affect the overall metabolism through alterations in both the behavior of the key enzymes of important pathways (Shah et al., 2001), and membrane composition and function (Fodor et al., 1995; Madejón et al., 2006), including lowering the control of the cell redox state which ultimately causes oxidative stress (Gratao et al., 2005). Cadmium inhibits the photoactivation of photosystem 2 (PS2) by inhibiting electron transfer (Kudo et al., 2011). Hence, Cd can lead to the generation of reactive oxygen species (ROS) indirectly by production of disturbances in the chloroplasts. As a non-redox metal, $\mathrm{Cd}$ is unable to perform single electron transfer reactions, and hence does not directly produce ROS such as the superoxide anion $\left(\mathrm{O}_{2}{ }^{\bullet-}\right)$, singlet oxygen $\left({ }^{1} \mathrm{O}_{2}\right)$, hydrogen peroxide $\left(\mathrm{H}_{2} \mathrm{O}_{2}\right)$, and hydroxyl radical $(\mathrm{OH})$, but thought to generate oxidative stress by interfering with the antioxidant defence system (Tran and Popova, 2013). In addition, some other reports suggested that $\mathrm{Cd}$ may stimulate the production of ROS in the mitochondrial electron transfer chain (Hassan and Aarts, 2011). Acid phosphatase and alkaline phosphatase activity can be used as marker enzymes for Cd toxicity in plant as the enzymes have been shown to be sensitive to $\mathrm{Cd}$. Also the toxicity of $\mathrm{Cd}$ has been related with the increase of lipid peroxidation and alterations in antioxidant systems in plants (Fornazier et al., 2002; Tran and Popova, 2013).

Lipid peroxidation is the destructive oxidative process by ROS or nitrogen radicals of animals and plants fatty acids (Kudo et al., 2011). Thus, these polyunsaturated fatty acids are converted to lipid hydroperoxides $(\mathrm{LOOH})$, rendering damage to biological membrane (Khan et al., 2013).

Alkaline phosphatase (ALP) is a hydrolase with sole function to removing phosphate groups from biological molecules including nucleotides, proteins and alkaloids. The process of removing the phosphate group is called dephosphorylation (Coleman, 1992). The presence of phosphate groups usually prevents organic molecules from passing through the membrane; therefore, dephosphorylating them may be important for plant uptake of organic compounds (Coleman, 1992; Chatchawal et al., 2008).

Acid phosphatases are widely distributed in plants and significantly differ in their susceptibility to inhibition by various compounds (Penheiter et al., 1997). Acid phosphatases specifically catalyze the hydrolysis of a variety of phosphate esters in acidic environment and these enzymes function in the maintenance of the phosphorus status of the plant, particularly with accessing phosphorus from the soil (Duff et al., 1994). Several factors have been shown to influence acid phosphatase activity; however, heavy metals effect on acid phosphatase is poorly understood.

Removal of excess metal ion from the soil is brought by chemical as well as biological means. Chemical remediation involves the use of chemicals to clean the environment, however, this cannot be considered universal as one chemical cannot be used for all metal ions (Shah et al., 2001). Examples of chemicals used for remediating Cd pollution in soils are, EDTA and pyrene.

Ethylenediaminetetraacetic acid with the formula $\left[\mathrm{CH}_{2} \mathrm{~N}\left(\mathrm{CH}_{2} \mathrm{CO}_{2} \mathrm{H}\right)_{2}\right]_{2}$, is a polyamino carboxylic acid. Its usefulness arises because of its ability to sequester metal ions such as $\mathrm{Fe}^{3+}, \mathrm{Cd}^{2+}, \mathrm{Pb}^{2+}$, etc. After being bound by EDTA, metal ions remain in solution but exhibit diminished reactivity. Hence, it is important in biological system as a chelating agent. The complex of EDTA with $\mathrm{Cd}$ reduces its uptake by plants. However, very little work has been done on the effect of EDTA on Cd toxicity in plants. Hence, this study, specifically, investigated the effect of EDTA on germination, growth, fresh weight, root acid and alkaline phosphatase activity as well as root lipid peroxidation of $\mathrm{Cd}$ treated Zea mays $\mathrm{L}$ and Vigna unguiculata $\mathrm{L}$. The results shows the co-treatment of $\mathrm{Cd}$ treated maize and cowpea seedlings with EDTA at 0.5 $\mathrm{mM}$ and $1.0 \mathrm{mM}$ reversed the inhibition of growth rate, levels of SOD and catalase, acid and alkaline phosphatase activities in both seedlings.

\section{MATERIALS AND METHODS}

\section{Plant materials and soil samples preparation}

Maize (Zea. mays) and cowpea (Vigna unguiculata) seeds used for the study were sourced locally. Humus soil was sieved to remove debris and stones of the sieved soil $(1.4 \mathrm{~kg})$ was weighed and treated with $100 \mathrm{ml}(100 \mathrm{mg} / \mathrm{L})$ cadmium chloride $\left(\mathrm{CdCl}_{2}\right)$, and 100 $\mathrm{ml}(0.1 \mathrm{M})$ EDTA). The control soil was similarly treated with $100 \mathrm{ml}$ of water before planting in perforated bags. Treatment of the soil was carried out by gradual mixing in a solution of $\mathrm{CdCl}_{2}$ alone, and $\mathrm{CdCl}_{2}$ containing $0.5 \mathrm{ml}(1.0 \mathrm{mM}$ EDTA) for the experimental samples. The control soil was treated with an equivalent volume of water.

\section{Experimental design}

The seeds of maize and cowpea, sown in various treated soils are described above. The polyethene bags containing the soil implanted with maize seedlings were kept in a greenhouse for germination. Each treatment including control consisted of a set of 3 seeds per bag and was replicated seven times. All treated soil was kept moist with water to aid seed germination. Record of seed germination was taken after first, second, third, and fourth day of germination, respectively, and the seeds which fails to grow or sprout after that time was regarded as not germinated. Plants from each treatment group were harvested after 7 and 21 days, respectively for morphological and biochemical studies.

\section{Early seedling growth}

Early seedling growth rate was measured using vine length of 7 and 
Table 1. Effect of EDTA on length of stem, fresh weight and area of leaf of cadmium treated maize seedlings.

\begin{tabular}{|c|c|c|c|c|}
\hline Parameter & Control & $100 \mathrm{mg} / \mathrm{L} \mathrm{Cd}^{2+}$ & $\begin{array}{c}100 \mathrm{mg} / \mathrm{L} \mathrm{Cd}^{2+}+ \\
0.5 \mathrm{~mm} \text { EDTA }\end{array}$ & $\begin{array}{c}100 \mathrm{mg} / \mathrm{L} \mathrm{Cd}^{2+}+1.0 \\
\mathrm{~mm} \text { EDTA }\end{array}$ \\
\hline \multicolumn{5}{|l|}{7 days } \\
\hline Length of stem $(\mathrm{cm})$ & $11.2 \pm 0.28^{\mathrm{a}}$ & $9.6 \pm 0.53^{b}$ & $11.1 \pm 1.12^{\mathrm{a}}$ & $11.1 \pm 0.66^{a}$ \\
\hline Fresh weight $(\mathrm{g})$ & $2.25 \pm 0.28^{\mathrm{a}}$ & $1.73 \pm 0.10^{b}$ & $2.02 \pm 0.41^{a}$ & $1.86 \pm 0.42^{b}$ \\
\hline Area of leaf $\left(\mathrm{cm}^{2}\right)$ & $39.9 \pm 10.29^{a}$ & $29.0 \pm 2.49^{b}$ & $29.3 \pm 3.24^{b}$ & $33.1 \pm 3.32^{\mathrm{C}}$ \\
\hline \multicolumn{5}{|l|}{21 days } \\
\hline Length of stem $(\mathrm{cm})$ & $16.5 \pm 1.29^{\mathrm{a}}$ & $14.3 \pm 0.45^{b}$ & $14.5 \pm 1.73^{b}$ & $15.9 \pm 1.14^{\mathrm{a}}$ \\
\hline Fresh weight $(\mathrm{g})$ & $5.82 \pm 0.60^{\mathrm{a}}$ & $3.72 \pm 0.98^{b}$ & $4.24 \pm 1.08^{\mathrm{C}}$ & $3.66 \pm 0.52^{b}$ \\
\hline Area of leaf $\left(\mathrm{cm}^{2}\right)$ & $64.8 \pm 18.02^{\mathrm{a}}$ & $47.8 \pm 8.46^{\mathrm{b}}$ & $63.1 \pm 0.45^{\mathrm{a}}$ & $49.8 \pm 6.76^{b}$ \\
\hline
\end{tabular}

21 day old plants. The vine length was measured from the soil level of the terminal bud.

\section{Measurement of fresh weight}

Fresh weight was determined from specimens of 7 and 21 days old maize and cowpea plants using the Setra BL-40s precision electronic balance. The uprooted specimen were carefully rinsed with portable water and dried before weighing.

\section{Measurement of leaf length and weight}

Leaf lengths were determined from specimen of 7 and 21 days old seedlings using a ruler and its value recorded in $\mathrm{cm}^{2}$.

\section{Collection of samples}

The roots of maize plants were collected randomly from each of the treatment group as pooled samples. These roots, pooled together as a sample were used for biochemical analysis. They were stored at $-10^{\circ} \mathrm{C}$ until required for homogenization, done within $24 \mathrm{~h}$.

\section{Preparation of samples}

Weighed quantities of roots were homogenized in pre-chilled mortar using $5 \mathrm{ml}$ of $1-\mathrm{X}$ normal saline $(0.9 \% \mathrm{NaCl})$ solution. The homogenate was centrifuged at a speed of $5000 \times \mathrm{g}$ and the supernatant transferred into a labeled test tube until required for biochemical analysis.

\section{Assay for acid and alkaline phosphatase}

The activity of acid and alkaline phosphatase was determined using the method of Giese (1971). The amount of p-nitrophenol produced was estimated from a standard curve. The activity of the enzyme is expressed as $\mu$ mole p-nitrophenol produced $/ \mathrm{min}^{1} / \mathrm{ml}$.

\section{Assay for lipid peroxidation}

Level of lipid peroxidation was determined using the method of Gutteridge and Wilkins (1982), and Halliwell and Gutteridge (1984).

\section{Statistical data analysis}

The data are presented as \pm standard error of mean (SEM), [following similar analysis by Nwachukwu et al. (2014) and Nwose et al. (2015)] and are analysed statistically by one-way analysis of variance (ANOVA). This is followed by Duncan's multiple range test using SPSS 10.0 computer software package (SPSS Inc., Chicago, U.S.A). The correlation analysis was performed, quoting the Pearson correlation coefficients and test of significance, with significance accepted at $\mathrm{P} \leq<0.05$.

\section{RESULTS}

The present study investigated the effect of EDTA on Cd toxicity in plants using maize (Z. mays) and cowpea ( $V$. unguiculata) as plant model. Moreover, the experiments was also designed to establish the effect of EDTA on germination, growth, fresh weight, root acid and alkaline phosphatase activity as well as root lipid peroxidation of $\mathrm{Cd}$ treated $Z$. mays $\mathrm{L}$. and $V$. unguiculata $\mathrm{L}$. as these were critically examined.

The effect of EDTA on length of stem, fresh weight and area of leaf of $\mathrm{Cd}$ treated maize seedlings is presented in Table 1. The length of stem of $\mathrm{Cd}$ (in soil exposed) treated plants was significantly decreased in relation to control after 7 days of germination. Conversely, the $\mathrm{Cd}$ and EDTA significantly increased the length of stem of the plants as compared to the plants treated with Cd only. The length of stem was not significantly different from the control after 7 days of germination.

A similar trend was observed in maize plants treated for 21 days, with exposure to $\mathrm{Cd}$ (Table 1). However, supplementation of the soil with $1.0 \mathrm{mM}$ EDTA reversed the effects of $\mathrm{Cd}$ on the length of stem of maize plants (Table 1), while no significant changes was observed in this parameter in plants grown in soils treated with $\mathrm{Cd}$ and $0.5 \mathrm{mM}$ EDTA as compared to those grown in soils treated with $\mathrm{Cd}$ alone. The fresh weight of $\mathrm{Cd}$ treated plants was significantly decreased relative to control after 7 days of germination. However, supplementation of the soil with $0.5 \mathrm{mM}$ EDTA reversed the effects of $\mathrm{Cd}$ on 
Table 2. Effect of EDTA on length of stem, fresh weight and area of leaves of cadmium treated cowpea plants.

\begin{tabular}{|c|c|c|c|c|}
\hline Parameter & Control & $100 \mathrm{mg} / \mathrm{L} \mathrm{Cd}^{2+}$ & $\begin{array}{c}100 \mathrm{mg} / \mathrm{L} \mathrm{Cd}^{2+}+0.5 \\
\mathrm{~mm} \text { EDTA }\end{array}$ & $\begin{array}{c}100 \mathrm{mg} / \mathrm{L} \mathrm{Cd}^{2+}+1.0 \\
\mathrm{~mm} \text { EDTA }\end{array}$ \\
\hline \multicolumn{5}{|l|}{7 days } \\
\hline Length of stem $(\mathrm{cm})$ & $20.1 \pm 0.42^{\mathrm{a}}$ & $19.6 \pm 1.69^{\mathrm{a}}$ & $20.51 \pm 0.54^{\mathrm{a}}$ & $23.32 \pm 0.84^{b}$ \\
\hline Fresh weight $(\mathrm{g})$ & $1.96 \pm 0.06^{\mathrm{a}}$ & $1.66 \pm 0.35^{\mathrm{a}}$ & $1.85 \pm 0.11^{\mathrm{a}}$ & $1.80 \pm 0.22^{\mathrm{a}}$ \\
\hline Area of leaf $\left(\mathrm{cm}^{2}\right)$ & $36.75 \pm 2.71^{\mathrm{a}}$ & $35.05 \pm 4.24^{\mathrm{a}}$ & $36.27 \pm 26.7^{\mathrm{a}}$ & $27.01 \pm 2.13^{b}$ \\
\hline \multicolumn{5}{|l|}{21 days } \\
\hline Length of stem $(\mathrm{cm})$ & $27.8 \pm 2.21^{\mathrm{a}}$ & $22.7 \pm 3.16^{\mathrm{b}}$ & $24.87 \pm 2.71^{\mathrm{c}}$ & $24.6 \pm 3.71^{c}$ \\
\hline Fresh weight $(\mathrm{g})$ & $5.16 \pm 1.143^{\mathrm{a}}$ & $2.35 \pm 0.65^{b}$ & $4.05 \pm 1.14^{\mathrm{a}}$ & $4.59 \pm 2.303^{\mathrm{a}}$ \\
\hline Area of leaf $\left(\mathrm{cm}^{2}\right)$ & $35.94 \pm 10.58^{\mathrm{a}}$ & $31.73 \pm 4.73^{b}$ & $34.57 \pm 10.04^{\mathrm{a}}$ & $25.34 \pm 5.21^{\mathrm{c}}$ \\
\hline
\end{tabular}

Results expressed as mean \pm standard deviation (SD). Values with the same letters are not significantly different $(p>0.05)$.

fresh weight of the maize plant, while no significant changes was observed in this parameter in plants grown in soils treated with both $\mathrm{Cd}$ and $1.0 \mathrm{mM}$ EDTA as compared to those treated with $\mathrm{Cd}$ alone. The fresh weight of the plants treated with both $\mathrm{Cd}$ and $0.5 \mathrm{mM}$ EDTA were not significantly different from the control after 7 days of germination.

Also, the exposure of the plants to Cd decreased fresh weight relative to control after 21 days of germination. However, supplementation of the soil with $0.5 \mathrm{mM}$ EDTA significantly increased fresh weight of maize plant, while no significant change was observed in fresh weight of plants grown in soils treated with both $\mathrm{Cd}$ and $1.0 \mathrm{mM}$ EDTA as compared to those grown in soils treated with Cd alone (Table 1). The fresh weight of plants treated with both $\mathrm{Cd}$ and $0.5 \mathrm{mM}$ EDTA was also significantly different from the control after 21 days of germination.

The area of leaf of $\mathrm{Cd}$ treated plants (grown in cadmium treated soil) was significantly decreased relative to control after 7 and 21 days of germination. Supplementation of the soil with 1.0 and $0.5 \mathrm{mM}$ EDTA significantly increased leaf area of the maize plants relative to the plants treated with $\mathrm{Cd}$ after 7 and 21 days, respectively. Thus, the study shows that EDTA reversed the effect of $\mathrm{Cd}$ on morphological parameters of maize seedling, albeit, the influence of EDTA was not dose dependent.

Similarly, the effects of EDTA on length of stem, fresh weight and area of leaf of $\mathrm{Cd}$ treated cowpea plant were studied and the results presented in Table 2.

The length of stem of $\mathrm{Cd}$ treated cowpea plants showed no significant difference relative to control after 7 days of germination, but was significantly decreased relative to control after 21 days (Table 2). The effects of $\mathrm{Cd}$ on length of stem of the plants was reversed by addition of $0.5 \mathrm{mM}$ concentrations of EDTA after 21 days of germination as the stem length of the plants was significantly increased relative to $\mathrm{Cd}$ treated plants.

Moreover, the fresh weight of $\mathrm{Cd}$ treated cowpea plants was not significantly different relative to control after 7 days of germination, neither did the administration of
EDTA alter the fresh weight of the Cd treated plants as compared to plants treated with $\mathrm{Cd}$ after the same period of exposure (Table 2). As noticed, the fresh weight of $\mathrm{Cd}$ treated cowpea plants was significantly decreased after 21 days relative to the plants treated with $\mathrm{Cd}$ only. However, treatment of the $\mathrm{Cd}$ treated cowpea plants with both concentrations ( 0.5 to $1.0 \mathrm{mM}$ ) of EDTA restored the fresh weight of the plants to levels comparable with the control.

The area of leaf of Cd treated cowpea plants was significantly decreased relative to control after 21 days of germination however, no significant difference was observed after 7 days. The simultaneous treatment of plants with $\mathrm{Cd}$ and $0.5 \mathrm{mM}$ EDTA significantly increased the area of leaf of the 21 days plants relative to plants treated with only $\mathrm{Cd}$ (Table 2), whilst the simultaneous treatment of the plant with $\mathrm{Cd}$ and $1.0 \mathrm{mM}$ EDTA appear to be adverse as it decreased leaf area as compared to other experimental groups (Table 2). Thus, the study also established that morphological parameters of cowpea were significantly decreased after 21 days of germination and the co-treatment of $\mathrm{Cd}$ treated cowpea plants with EDTA tend to restore the levels of these parameters as they were significantly increased relative to plants treated with $\mathrm{Cd}$ only, albeit the effectiveness of EDTA was not specific to a concentration.

Also, the effect of EDTA on root acid phosphatase activity of $\mathrm{Cd}$ treated maize plants was studied (Table 3 ). The root acid phosphatase activity of $\mathrm{Cd}$ treated maize plants was significantly decreased relative to control after 7 and 21 days of germination. The co-treatment of maize plants with $\mathrm{Cd}$ using both concentrations of EDTA was observed to significantly increase root acid phosphatase activity at 7 and 21 days of germination as compared to plants treated with $\mathrm{Cd}$ only.

Tables 4 and 5 show the effect of EDTA on root alkaline phosphatase activity of $\mathrm{Cd}$ treated maize and cowpea plants, respectively. The result data shows no significant change in root alkaline phosphatase activity in both control and test soils after 7 days. However, the root alkaline phosphatase activity of $\mathrm{Cd}$ treated plants was 
Table 3. Effect of EDTA on root alkaline acid phosphatase activity of cadmium treated maize plants.

\begin{tabular}{|c|c|c|c|c|}
\hline Parameter & Control & $100 \mathrm{mg} / \mathrm{L} \mathrm{Cd}^{2+}$ & $\begin{array}{c}100 \mathrm{mg} / \mathrm{L} \mathrm{Cd}^{2+}+0.5 \\
\mathrm{~mm} \text { EDTA }\end{array}$ & $\begin{array}{c}100 \mathrm{mg} / \mathrm{L} \mathrm{Cd}^{2+}+ \\
1.0 \mathrm{~mm} \text { EDTA }\end{array}$ \\
\hline \multicolumn{5}{|l|}{7 days } \\
\hline Alkaline phosphatase & $7.75 \pm 0.526^{a}$ & $7.50 \pm 0.346^{b}$ & $7.55 \pm 0.300^{\mathrm{a}}$ & $7.70 \pm 0.740^{\mathrm{a}}$ \\
\hline \multicolumn{5}{|l|}{ Umol/PNP/min/ml } \\
\hline Acid phosphatase & $39.9 \pm 10.29^{a}$ & $2.22 \pm 0.218^{b}$ & $2.39 \pm 0.679^{b}$ & $2.68 \pm 0.197^{\mathrm{C}}$ \\
\hline \multicolumn{5}{|l|}{21 days } \\
\hline Alkaline phosphatase & $12.07 \pm 0.946^{\mathrm{a}}$ & $8.15 \pm 1.099^{b}$ & $9.67 \pm 0.582^{\mathrm{C}}$ & $10.38 \pm 0.462^{c}$ \\
\hline \multicolumn{5}{|l|}{ Umol/PNP/min/ml } \\
\hline Acid phosphatase & $5.04 \pm 0.621^{a}$ & $3.47 \pm 0.315^{\mathrm{b}}$ & $4.00 \pm 0.194^{c}$ & $4.16 \pm 1.275^{\mathrm{c}}$ \\
\hline
\end{tabular}

Table 4. Effect of EDTA on level of alkaline acid phosphatase in roots of cadmium treated cowpea plant.

\begin{tabular}{|c|c|c|c|c|}
\hline Parameter & Control & $100 \mathrm{mg} / \mathrm{L} \mathrm{Cd}^{2+}$ & $\begin{array}{c}100 \mathrm{mg} / \mathrm{L} \mathrm{Cd}^{2+}+ \\
0.5 \mathrm{~mm} \text { EDTA }\end{array}$ & $\begin{array}{c}100 \mathrm{mg} / \mathrm{L} \mathrm{Cd}^{2+}+1.0 \\
\mathrm{~mm} \text { EDTA }\end{array}$ \\
\hline \multicolumn{5}{|l|}{7 days } \\
\hline Alkaline phosphatase & $17.8 \pm 1.68^{\mathrm{a}}$ & $16.7 \pm 1.79^{\mathrm{a}}$ & $17.0 \pm 3.40^{\mathrm{a}}$ & $17.0 \pm 1.20^{\mathrm{a}}$ \\
\hline Acid phosphatase & $3.3 \pm 0.37^{\mathrm{a}}$ & $2.03 \pm 0.45^{b}$ & $2.3 \pm 0.62^{b}$ & $3.38 \pm 0.75^{a}$ \\
\hline \multicolumn{5}{|l|}{21 days } \\
\hline Alkaline phosphatase & $21.8 \pm 1.804^{\mathrm{a}}$ & $13.2 \pm 1.407^{b}$ & $18.2 \pm 2.250^{c}$ & $19.5 \pm 1.804^{c}$ \\
\hline Acid phosphatase & $5.3 \pm 0.86^{\mathrm{a}}$ & $4.6 \pm 0.41^{\mathrm{b}}$ & $5.1 \pm 0.37^{\mathrm{a}}$ & $5.41 \pm 1.13^{\mathrm{c}}$ \\
\hline
\end{tabular}

Results are expressed as mean \pm standard deviation (SD). Values with same letters are not significantly different $(p>0.05)$.

Table 5. Effect of EDTA on levels of SOD, catalase and lipid peroxidation in roots of cadmium treated maize seedlings.

\begin{tabular}{|c|c|c|c|c|}
\hline Parameter & Control & $100 \mathrm{mg} \mathrm{Cd} / \mathrm{L}$ & $\begin{array}{c}100 \mathrm{mg} \mathrm{Cd} / \mathrm{L}+0.05 \\
\mathrm{mM} \text { EDTA }\end{array}$ & $\begin{array}{c}100 \mathrm{mgCd} / \mathrm{L}+1.0 \\
\mathrm{mM} \text { EDTA }\end{array}$ \\
\hline \multicolumn{5}{|l|}{ 7days } \\
\hline SOD & $74.5 \pm 4.2^{\mathrm{a}}$ & $52.6 \pm 3.5^{b}$ & $70.0 \pm 7.5^{\mathrm{a}}$ & $68.5 \pm 6.4^{\mathrm{a}}$ \\
\hline CAT & $2.56 \pm 0.4^{\mathrm{a}}$ & $1.8 \pm 0.3^{\mathrm{b}}$ & $2.4 \pm 0.3^{\mathrm{a}}$ & $2.6 \pm 0.4^{\mathrm{a}}$ \\
\hline LPO & $413.0 \pm 16.77^{\mathrm{a}}$ & $469.0 \pm 12.45^{b}$ & $445.4 \pm 9.64^{b}$ & $484.7 \pm 4.51^{\mathrm{C}}$ \\
\hline \multicolumn{5}{|l|}{21 days } \\
\hline SOD & $60.2 \pm 4.5^{\mathrm{a}}$ & $34.5 \pm 3.0^{\mathrm{b}}$ & $58.5 \pm 3.6^{\mathrm{a}}$ & $45.0 \pm 4.0^{c}$ \\
\hline CAT & $2.3 \pm 0.6^{\mathrm{a}}$ & $1.2 \pm 0.3^{\mathrm{b}}$ & $2.4 \pm 0.5^{\mathrm{a}}$ & $1.8 \pm 0.6^{c}$ \\
\hline LPO & $412.1 \pm 19.46^{\mathrm{a}}$ & $657.1 \pm 17.4^{\mathrm{b}}$ & $621.3 \pm 8.80^{\mathrm{b}}$ & $652.1 \pm 17.47^{b}$ \\
\hline
\end{tabular}

Results expressed as mean \pm standard deviation (SD). SOD, Super oxide dismutase; LPO, lipid peroxidation; CAT, catalase.

significantly decreased after 21 days of germination. Thus, the treatment of maize and cowpea plants with $\mathrm{Cd}$ at both concentrations of EDTA (0.5 and $1.0 \mathrm{mM}$ EDTA) significantly increased root alkaline phosphatase after 21 days of germination as compared to plants treated with Cd only. These results are firm indication that both 
Table 6. Effect of EDTA on levels of SOD, catalase and lipid peroxidation in roots of cadmium treated cowpea seedlings.

\begin{tabular}{lcccc}
\hline Parameter & Control & $\mathbf{1 0 0 ~} \mathbf{~ g ~ C d} / \mathbf{L}$ & $\mathbf{1 0 0} \mathbf{~ m ~ C d} / \mathbf{L}+\mathbf{0 . 0 5} \mathbf{~ m M ~ E D T A ~}$ & $\mathbf{1 0 0 ~} \mathbf{~ g C d} / \mathbf{L}+\mathbf{1 . 0} \mathbf{~ m M ~ E D T A ~}$ \\
\hline 7days & & & & \\
SOD & $85.0 \pm 5.2^{\mathrm{a}}$ & $40.8 \pm 4.0^{\mathrm{b}}$ & $63.5 \pm 4.5^{\mathrm{c}}$ & $48.0 \pm 3.8^{\mathrm{b}}$ \\
CAT & $2.8 \pm 0.6^{\mathrm{a}}$ & $1.5 \pm 0.2^{\mathrm{b}}$ & $2.7 \pm 0.4^{\mathrm{a}}$ & $1.2 \pm 0.2^{\mathrm{b}}$ \\
LPO & $333.3 \pm 10.8^{\mathrm{a}}$ & $463.8 \pm 8.33^{\mathrm{b}}$ & $441.0 \pm 9.5^{\mathrm{c}}$ & $420.0 \pm 4.4^{\mathrm{c}}$ \\
& & & \\
21 days & & & & $75.4 \pm 5.0^{\mathrm{a}}$ \\
SOD & $80.0 \pm 4.5^{\mathrm{a}}$ & $54.2 \pm 4.0^{\mathrm{b}}$ & $78.5 \pm 4.0^{\mathrm{a}}$ & $2.5 \pm 0.3^{\mathrm{a}}$ \\
CAT & $2.5 \pm 0.3^{\mathrm{a}}$ & $2.3 \pm 0.2^{\mathrm{a}}$ & $2.4 \pm 0.2^{\mathrm{a}}$ & $573.0 \pm 10.5^{\mathrm{c}}$ \\
LPO & $358.81 \pm 8.35^{\mathrm{a}}$ & $635.5 \pm 4.53^{\mathrm{b}}$ & $599.4 \pm 5.97^{\mathrm{c}}$ & \\
\hline
\end{tabular}

Results expressed as mean \pm standard deviation (SD). Values with same letters are not significantly different $(p>0.05)$. SOD, Super oxide dismutase; LPO, lipid peroxidation; CAT, catalase.

concentrations of EDTA reversed the effects of Cd on root alkaline phosphatase activity after 21 days of germination.

The effect of EDTA on level of root SOD, catalase and lipid peroxidation of cadmium treated maize and cowpea seedlings are presented in Table 6. Conversely, the level of lipid peroxidation of both $\mathrm{Cd}$ treated maize and cowpea plants were significantly increased relative to control after 7 and 21 days of germination, whereas that of SOD and catalase were significantly decreased after 7 and 21 days except for catalase activity of cowpea after 21 days. The simultaneous treatment of maize seedlings with both concentrations of EDTA could not restore the level of lipid peroxidation induced by $\mathrm{Cd}$ relative to control although there was a significant decrease for cowpea. However, supplementation with 0.5 and $1.0 \mathrm{mM}$ EDTA restored the activity of SOD and catalase compared to test for maize after 7 and 21 days. On administration of $0.5 \mathrm{mM}$ EDTA to Cd-treated cowpea seedlings, a significant increase was observed in the levels of SOD and catalase compared to Cd-treated cowpea plants. No significant change was seen on treatment with $1.0 \mathrm{mM}$ EDTA except for SOD level after 21 days.

\section{DISCUSSION}

Cadmium from various sources of chemical pollutants accumulates in the soil and is taken up by plants (Ernst, 1980). In the present study, a weighed quantity of soil $(1.4 \mathrm{~kg})$ was treated with $100 \mathrm{ml}(100 \mathrm{mg} \mathrm{Cd} / \mathrm{L})$, two solutions of $100 \mathrm{mg} \mathrm{Cd} / \mathrm{L}$ containing $0.5 \mathrm{mM}$ EDTA, and $100 \mathrm{mg} \mathrm{Cd} / \mathrm{L}$ containing $1.0 \mathrm{mM}$ EDTA and an equivalent volume of water was used for control samples. Seeds of maize ( $Z$. mays L.) and cowpea ( $V$. unguiculata $L$.) were planted in these soils. The percentage germination, length of stem, area of leaves, fresh weight as well as root acid phosphatase and root alkaline phosphatase and levels of root lipid peroxidation, SOD and catalase were monitored on both plants and comparison made to show the level of cadmium toxicity and possible effects of EDTA on cadmium treated plants.

Generally, there are five basic applications of $\mathrm{Cd}$. About three-fourth of $\mathrm{Cd}$ is used as electrode materials in nickel-cadmium batteries; most of the remaining onefourth is used mainly as pigment in plastics and glasses, protective plating for steel, stabilizers for plastic (Poly Vinyl Chloride (PVC), and as a component of various alloys. Also, Cd has ability to absorb neutons, so it is used as a barrier to control nuclear fission (Scoullos et al., 2001). Recently, the role of $\mathrm{Cd}$ in biology was discovered, as carbon dependent carbonic anhydrase has been found in matrine diatoms. Cadmium does the same job as zinc in other anhydrases, but the diatoms live in environment with very low zinc concentrations, thus biology has taken $\mathrm{Cd}$ rather than zinc (Lane and Morel, 2000; Lane et al., 2005).

Results obtained from the study, show that germination of both maize and cowpea seeds were not influenced by treatment with $\mathrm{Cd}$ alone or the co-treatment of $\mathrm{Cd}$ and EDTA at 0.5 and $1.0 \mathrm{mM}$ concentrations, respectively. This, result suggests that $\mathrm{Cd}$ has no effect on the germinating ability of the plants, which may not be surprising as they lack prominent roots at early stage of seed germination. Similar results have been reported previously (Dong et al., 2006). Thus, growth rate which was assessed by the length of stem, fresh weight and areas of leaf of $\mathrm{Cd}$ treated maize and cowpea seedlings was inhibited at 7 and 21 days of exposure, an indication of toxicity of the metal on these plants (Table 1). This retardation in growth rate could be due to interference with mineral station, which hampered the uptake and translocation of essential elements (Dong et al., 2006).

Previous study by $\mathrm{Ci}$ et al. (2009), reported that heavy metals such as $\mathrm{Cd}$ affects plants by inhibiting the normal uptake and utilization of mineral nutrients within the plant cells. Hence, high amounts of $\mathrm{Cd}$ therefore may lead to the displacement of micronutrients such as; $\mathrm{Zn}, \mathrm{Mn}, \mathrm{Fe}$, etc. including other essential nutrient sharing similar valency from their sites of action. This may in turn lead to 
physiological changes resulting in the stimulation of some enzymatic activities that limit cell growth and consequently accelerating tissue senescence (De-Pasquale et al., 1988; Dunwei et al., 2009). Therefore, the significant decrease in root acid phosphatase (Tables 4 and 5), and alkaline phosphatase activities of $\mathrm{Cd}$ treated maize and cowpea seedlings may be due to the displacement of metal ion cofactors for example $\mathrm{Mg}^{2+}$ by $\mathrm{Cd}$ at high concentration from the active site of the enzyme as both phosphatase are metallo-enzymes. Furthermore, other possible mechanisms for $\mathrm{Cd}$ toxicity in plants at high concentrations can and may be through its interference with $\mathrm{PO}_{4}{ }^{3-}$ binding sites of the enzymes (Gonçalves et al., 2007).

The exposure of maize and cowpea seedling to $\mathrm{Cd}$ treated soil for 7 and 21 days caused an increase in level of root lipid peroxidation of the plants (Table 6). Similar trend has been reported in Phaseolus vulgaris (Sandalio et al., 2001; Chaoui et al., 1997), Helliantus annuus (Benavides et al., 2005), Pisum sativum plant (LozanoRodriguez et al., 1997) which caused irreversible damage to cell function thus affecting growth rate. However, both concentrations of EDTA $(0.5 \mathrm{mM}$ and $1.0 \mathrm{mM})$ reversed the $\mathrm{Cd}$-induced increase in level of root lipid peroxidation in $\mathrm{Cd}$ treated cowpea seedling after 7 and 21 days of exposure.

Ethylenediaminetetraacetic acid is known to be a good chelating agent, hence, in biological systems, EDTA are used to bind metal ions in the form of chelation therapy, e.g. for mercury and lead poisoning. It is used in similar manner to remove excess iron from the body (Huldé and Harju, 1980). This therapy is used to treat the complication of repeated blood transfusions, as would be applied to patient with thalassemia phenotype. EDTA acts as a powerful antioxidant to prevent radicals from injuring blood vessel walls (Lamas et al., 2014).

Results obtained in the present study show that the toxicity conferred on maize and cowpea seedlings by $\mathrm{Cd}$ stress was reversed when test soils were supplemented with EDTA at 0.5 and $1.0 \mathrm{mM}$, respectively, albeit, effects was not dose dependent. This suggests that the supplementation of test soils with EDTA made Cd unavailable to the plants. Similarly, Wang et al. (2008) found that EDTA also affected $\mathrm{Cd}$ translocation from plant roots to plant shoots and that the complexation of EDTA with $\mathrm{Cd}$ reduced the uptake of $\mathrm{Cd}$ by plants. It has also been reported that the uptake of free $\mathrm{Cd}^{2+}$ in nutrient solution is diminished in the presence of EDTA, suggesting that the Cd-EDTA complex is unable to penetrate the membranes (Greger and Lindberg, 1986). Also, Debra et al. (2007) study, on the effect of chelating agents on Cd treated plants had shown EDTA to increase the aqueous solubility of $\mathrm{Cd}$ by 36 times over the soil matrix thereby increasing the possibility of leaching. Among all chelating agents used, EDTA has the most marked effect with a $45 \%$ reduction in total $\mathrm{Cd}$ (Debra et al., 2007).

The significantly higher levels of root lipid peroxidation of maize as compared to cowpea seedling after 7 and 21 days of germination is a likely indication that cowpea seedlings may be more tolerant than maize to Cd toxicity (Table 6).

It is however noteworthy that a higher concentration (1.0 mM EDTA) has an adverse effect on the growth parameters of $\mathrm{Cd}$ exposed cowpea (Table 2). Available studies had indicated in highly polluted environment, excessive uptake of EDTA, enhances uptake of metals, thus, increasing phytotoxicity. The fact is high internal concentration disturbs almost all physiological processes in plants. Despite achievements in sequestering $\mathrm{Cd}$ phytotoxicity, its physiological nature is not fully understood. Thus, it poses huge problems in regions of heavy metals pollution in which a sharp decrease in agricultural crop production has been observed.

Since $\mathrm{Cd}$ is readily taken up by root of many plant species with its toxicity considered to be far higher than that of other heavy metals; $\mathrm{Cd}$ pollution is of great interest in scientific research (Gussarson et al., 1996). Due mainly to modern industrial practices, more and more toxic ions are being added to the natural environment with adverse consequences to the ecosystem. Thus, metals like $\mathrm{Cd}$ and $\mathrm{Pb}$, present in high concentration in soil showed potential toxicity on overall growth and plants metabolism. The bio-accumulation of such toxic metals in plants possesses a threat to human and animal health.

In plants, it was previously established that $\mathrm{Cd}$ inhibits the photosynthetic rate with toxic $\mathrm{Cd}$ effects depending on the applied concentrations, the species and cultivation characteristics, the age of leaves and the phonological development of plants (Lagriffoul et al., 1998; Lux et al., 2004; Khan et al., 2013). The rate of photosynthesis, chlorophyll content, activities of photosystem 1 (ps1) and ps11 declined progressively with increasing concentration of applied Cd (Lux et al., 2004; Dunwei et al., 2009; Kudo et al., 2011). Moreover, human exposure to $\mathrm{Cd}$ and $\mathrm{Cd}$ containing compounds are known to be carcinogenic, hence can induce kidney dysfunction, renal disease that are characterized by severe tubular combined with glomerular disorders (Friberg, 1983).

\section{Conclusion}

Results of the present study show that the co-treatment of $\mathrm{Cd}$ treated maize and cowpea seedlings with EDTA at 0.5 and $1.0 \mathrm{mM}$, respectively reversed the inhibition of growth rate, levels of SOD and catalase, acid and alkaline phosphatase as well as activities in both seedlings. However, the effect of EDTA observed was not dose dependent.

\section{Conflicts of Interests}

The authors have not declared any conflict of interests. 


\section{REFERENCES}

Benavides MP, Gallego SM, Tomaro ML (2005). Cadmium toxicity in plants. Braz. J. Plant Physiol. 17(1):21-34.

Chandler AJ (1996). Characterizing cadmium in municipal solid waste. Sources of cadmium in the environment. Inter organisation program for sound management of chemical (IOMC), Organisation for Economic Co-operation and Development (OECD). Pads, France.

Chaoui A, Mazhvudi S, Ghorbal MH, El Ferjani E (1997). Cadmium and zinc induction enzymes activities in beans (Phaselous vulgaris L.). Plant Sci. 127:139-147.

Chatchawal W, Anchalee C, Wolfgang P (2008). Alkaline phosphatase as a sensitive marker. J. Plant Physiol. 165(16):1655-1666.

Ci DI, Jiang D, Dia T, Jing Q, Cao W (2009). Effects of cadmium on plant growth and physiological traits in contrast wheat recombinant inbred lines differing in cadmium tolerance. Chemosphere 77(11):1620-1625.

Coleman JE (1992). Structure and mechanisms of alkaline phosphatase. Ann. Rev. Biophys. Biomol. Struct. 21:441-446.

Debra L, Rachel C, Kevni K (2007).Effects of chelating agents and solubility of cadmium complexes in uptake from soil by Brassica juncea. Chemosphere 58(3):401-405.

De-Pasquale R, Ragusa S, Lauk L, Barbera R, Galati EM. (1988). Effects of cadmium on germination, growth and active principal content of Matricaria recutia L. Pharmacol. Res. Commun. 5:151-155.

Dong J, Wu F, Zhang G (2006).Influence of cadmium on antioxidant capacity and four microelement concentrations in tomato seedlings (Lycopersicon esculentum). Chemosphere 64:1659-1666.

Duff SMG, Sarath G, Plaxton WC (1994). The role of acid phosphatase in plant phosphorus metabolism. J. Plant Physiol. 90:791-800.

Dunwei C, Dong J, Jing Q, Weixing C (2009). Effects of cadmium on plant growth and physiological traits. Chemosphere 77(11):16201625.

Ernst W (1980). Biochemical aspect of cadmium in plants. In: cadmium in the environment. Niragu, J. (Ed.). Wiley and Sons, New York. pp. 639-653.

Fodor E, Szabo-Nagy A, Erdei L (1995). The Effects of Cadmium on the Fluidity and $\mathrm{H}^{+}$-ATPase Activity of Plasma Membrane from Sunflower and Wheat Roots. J. Plant Physiol. 147(1):87-92.

Fornazier RF, Ferreira RR, Vitoria AP, Molina SMG, Lea PJ, Azevedo RA (2002). Effects of Cadmium on Antioxidant Enzyme Activities in Sugar Cane. Biol. Plant. 45(1):91-97.

Friberg L (1984). Cadmium and Kidney Environm. Health Perspect. 54:1-11.

Giese AC (1971). Photosensitization by natural pigments. In: photophysiologyPhotophysiology vol 6. A.C Giese (Ed), Academic press, New York. pp. 77-129.

Gonçalves JF, Becker AG, Cargnelutti D, Luciane A, Tabaldi LA, Pereira LB, Battisti V, Spanevello RM, Morsch VM, Nicoloso FT, Schetinger MRC (2007). Cadmium toxicity causes oxidative stress and induces response of the antioxidant system in cucumber seedlings. Brazilian Braz. J. Plant Physiol. 19(3):56-60.

Gratao PL, Polle A, Lea PJ, Azevedo RA (2005). Making the life of heavy metal-stressed plants a little easier. Funct. Plant Biol. 32(6):481-494.

Greger M, Lindberg S (1986). Effects of $\mathrm{Cd}^{2+}$ and EDTA on young sugar beets (Beta vulgaris). I. $\mathrm{Cd}^{2+}$ uptake and sugar accumulation. Physiol. Plant. 66(1):69-74.

Gussarson M, Asp H, Adalsteinsson S, Jensén P (1996). Enhancement of cadmium effect on growth and nutrient composition of birch (Betula pendula) by buthionine sulphoximine (BSO). J. Exp. Bot. 47:211-215.

Gutteridge JMC, Wilkins S (1982). Cu-dependent hydroxyl radical damage to ascorbic acid. Formation of a thiobarbituric acid-reactive product. FEBS Lett. 137:327-330.

Halliwell B, Gutteridge JM (1984). Oxygen toxicity, oxygen radicals, transition metals and disease. Biochem. J. 219(1):1-14.

Hassan Z, Aarts MGM (2011). Opportunities and feasibilities for biotechnological improvement of $\mathrm{Zn}, \mathrm{Cd}$ or $\mathrm{Ni}$ tolerance and accumulation in plants. Environ. Exp. Bot. 72:53-63.

Huldé SG, Harju L (1980). Standardization of EDTA by spectrophotometric titration, with metallic copper as standard. Talanta 27(10):815-817
Khan MD, Mei L, Ali B, Chen Y, Cheng X, Zhu SJ (2013). CadmiumInduced Upregulation of Lipid Peroxidation and Reactive Oxygen Species Caused Physiological, Biochemical, and Ultrastructural Changes in Upland Cotton Seedlings. BioMed Res. Int. Article ID 374063, 10 p. doi:10.1155/2013/374063.

Kudo H, Kudo K, Ambo H, Uemura M, Kawai S (2011). Cadmium sorption to plasma membrane isolated from barley roots is impeded by copper association onto membranes. Plant Sci.180:300-305.

Lagriffoul A, Mocquot B, Mench M, Vangronsveld J (1998). Cadmium toxicity effects on growth, mineral and chlorophyll content and activities of stress related enzymes in young maize plants (Zea mays L.). Plant Soil 200:241-250.

Lamas GA, Boineau R, Goertz C, Mark DB, Rosenberg Y, Stylianou M, Rozema T, Nahin RL, Chappell TL, Lindblad L, Lewis EF, Drisko J Lee $\mathrm{KL}$ (2014). EDTA chelation therapy alone and in combination with oral high-dose multivitamins and minerals for coronary disease: The factorial group results of the trial to assess chelation therapy. Am. Heart J. 168(1):37-44.

Lane TW, Morel FM. (2000). A biological function for cadmium in marine diatoms. Proc. Nat. Acad. Sci. (9):4627-4631.

Lane TW, Saito MA, George GN, Pickering IJ, Prince RC, Morel FM (2005). Biochemistry: a cadmium enzyme from a marine diatom. Nature 435(7038):42-42.

Liu D, Jiang W, Gao X (2003). Effects of Cadmium on Root Growth, Cell Division and Nucleoli Root Tip Cells of Garlic. Biol. Plant. 47(1):7983.

Lozano-Rodriguez E, Hernandez LE, Bonay P, Carpena-Ruiz RO. (1997). Distribution of cadmium in shoot and root tissues1. J. Exp. Bot. 48(1):123-128.

Lux AA, Šotniková A, Opatrná J, Greger M (2004). Differences in structure of adventitious roots in Salix clones with contrasting characteristics of cadmium accumulation and sensitivity. Physiol. Plant. 120:537-545.

Madejón P, Murillo JT, Marañón T, Cabrera F (2006). Bioaccumulation of Trace Elements in a Wild Grass Three Years After the Aznalcóllar Mine Spill (South Spain). Environ. Monit. Assess. 114(1):169-189.

Nwachukwu KC, Asagba SO, Nwose C, Okoh MP (2014). Radiation Protection and Anti-oxidative Effects of Garlic, Onion and Ginger Extracts, x-ray Exposed Albino rats as Model for Biochemical Studies. Afr. J. Biochem. Res. 8(9):166-173.

Nwose C, Nwachukwu KC, Okoh MP (2015). Food chain Cadmium and Arsenic acid, effects on Plasma, tissue triglyceride concentration, experimental rats, as model study. Int. J. Chem. Stud. 3(2):102-108.

Penheiter AR, Duff SMG, Sarath G (1997). Soybean Root Nodule Acid Phosphatase. Plant Physiol. 114(2):597-604.

Rascio N, Vecchia FD, Ferretti M, Merlo L, Ghisi R (1993). Some effects of cadmium on maize plants. Arch. Environ. Contam. Toxicol. 25(2):244-249.

Sandalio LM, Dalurzo HC, Gomez M, Romero-Puertas MC, del Rio LA (2001). Cadmium-induced changes in the growth and oxidative metabolism of pea plants. J. Exp. Bot. 52(364):2115-2126.

Scoullos MJ, Vonkeman GH, Thornton I, Makuch Z. (2001). Mercury, Cadmium, Lead: Handbook for Sustainable Heavy Metals Policy and Regulation. Springer.

Shah K, Kumar RG, Verma S, Dubey RS. (2001). Effect of cadmium on lipid peroxidation, superoxide anion generation and activities of antioxidant enzymes in growing rice seedlings. Plant Sci. 161(6):1135-1144

Siedlecka A, Baszyń-Aski T (1993). Inhibition of electron flow around photosystem in chloroplasts of Cd-treated maize plants is due to $\mathrm{Cd}$ induced iron deficiency. Physiol. Plant. 87(2):199-202.

Tran TA, Popova LP (2013). Functions and toxicity of cadmium in plants: recent advances and future prospects. Turk. J. Bot. 37:1-13.

Wang L, Zhou Q, Ding L, Sun Y (2008). Effect of cadmium toxicity on nitrogen metabolism in leaves of Solanum nigrum $L$. as a newly found cadmium hyperaccumulator. J. Hazard. Mat. 154(1-3):818-825. 